\title{
Developing a Conceptual Framework for Simulation Analysis in a Supply Chain Based on Common Platform (SCBCP)
}

\author{
M. Fathollah ${ }^{1}$, F. Taham*2, A. Ashouri ${ }^{3}$ \\ ${ }^{1,2}$ Industrial Engineering Department, \\ Iran University of Science and Technology, Tehran, Iran \\ ${ }^{3}$ Industrial Engineering Department, \\ Sharif University of Technology, Tehran, Iran \\ *farzam@ind.iust.ac.ir
}

\begin{abstract}
As a competitive advantage in modern organizations, product diversification may cause complexities in today's extended supply chains. However, the Common Platform (CP) Strategy, as a concept of gaining maximum variety by minimum production elements, is believed to be one of the answers to eliminate or decrease these complexities. The main purpose of this paper is to provide a simulation framework for modeling the supply network of a case study in automotive industry in order to study the impacts of part commonality through the chain. The electrical wiring harness is selected as the main part to be studied according to essentiality and challenges of its procurement for the production of cars (as occurred in this case and many other studies). The paper does not provide the simulation results but it rather builds up the required foundation and gathers the relevant content to develop a realistic simulation model by closely studying the impacts of part multiplicity on different functional areas of the selected supply network and extracting the critical success factors of applying part commonality.
\end{abstract}

Keywords: Supply Chain Management, Common Platform, Part Commonality, Simulation Framework, Conceptual Modeling.

\section{RESUMEN}

Como ventaja competitiva en las organizaciones modernas, la diversificación de productos puede causar complejidades en las cadenas de suministro extendidas actuales. Sin embargo, se cree que la Estrategia de Plataforma Común (PC), como concepto relacionado con obtener máxima variedad con un mínimo de elementos de producción, es una de las respuestas para eliminar o disminuir estas complejidades. El objetivo principal de este trabajo es proporcionar un marco de simulación para modelar la red de suministro de un caso de estudio en la industria automotriz con el fin de estudiar los efectos de la estandarización de componentes a través de la cadena. Se ha elegido el arnés del cableado eléctrico como la parte principal a estudiarse por su esencialidad y desafíos que plantea su adquisición para la producción de automóviles (como ocurrió en este caso y en muchos otros estudios). El presente trabajo no proporciona los resultados de la simulación sino que más bien establece la base requerida y reúne el contenido adecuado para desarrollar un modelo realista de simulación estudiando cuidadosamente los efectos de la multiplicidad de partes en las diferentes áreas funcionales de la red de suministro seleccionada e identificando los factores críticos de éxito en la aplicación de la estandarización de componentes.

Palabras clave: Administración de cadenas de suministro, plataforma común, estandarización de componentes, marco de simulación, modelado conceptual.

\section{Introduction}

From new technology employment to implementation of improvement tools or application of managerial concepts, today's companies are faced with a tool box filled with different methods, concepts and ideas which are all declared as proper 'cures' or 'strengthening drugs' for their never ending thirst for

improvement. Not all these concepts and tools may be the best choice considering time and cost restrictions, and decision making under intense uncertainty may result in great market and profit loss. Therefore, organizations tend to leave the least part of their decision making process to chance and carefully analyze the systems they are dealing with. 
This paper is based upon a case study. An automotive company which has been driven into global car market and, therefore, needs to diversify its product portfolio as a competitive advantage. Important steps are taken in the diversification process but the product variety strategy has naturally caused great complexities in the company's supply network. As an example, the company is procuring 9 different types of main wiring harness for its 11 models of Samand cars which are nearly the same in technical specifications. The idea of communizing these different parts to be shared between the different models is in fact part of a more comprehensive concept called the "Common Platform". The Common Platform concept is based upon a basic idea of efficiently creating derivative products from a common foundation of technology, parts, processes, machines, and so on. This foundation is called "Platform".

Therefore, the main research questions are 1What are the main effects of implementing the Common Platform Strategy (in the form of Part Commonality) on the supply network of the mentioned company? And 2- Do the cost and time savings gained by resource sharing beat the expenditures and time dedicated to the implementation?

To provide answers for the first question, this paper defines a comprehensive concept called the "Supply Chain" based on the Common Platform (SCBCP) to build its analysis on. Then the paper tries to study the supply network of the selected firm. It defines the challenges of part proliferation in the company and the success factors induced by the application of CP strategy. The analytical approach in this stage is purely conceptual and based upon literature review, direct observation and expertise.

Concerning the second question, the paper uses the simulation tool. Simulation of course has been considered one of the most popular and exact methods for modeling complex industrial systems.
"The use of simulation for manufacturing systems design and analysis is rightfully recognized by scientists and industrial managers and the literature is abundant in this field" (Habchi \& Berchet, 2003). The paper presents a conceptual framework for simulation analysis of the case study supply network.

The research methodology used in this paper is based on the "analytical conceptual research" approach (Wacker, 1998; Merdith, 1998) and the "exploratory case study" (Ellram, 1996). This research methodology comprises new insights through logically developing relationships between carefully defined concepts into an internally consistent theory. These studies usually use case study examples to illustrate these conceptualizations. Figure 1 demonstrates the research steps followed by this paper.

It is important to note that the paper does not provide the simulation results for the defined case study. In fact by providing the integrated concept of SCBCP, the paper challenges the characteristics of the studied supply network and by providing a simulation framework, it paves the way for final analysis and comparison of results. The output analysis of simulation results (which is the final stage of the research roadmap in this paper) is currently being performed and will be provided in an upcoming paper.

This work is structured in the following manner: Section 1 defines the relevant concepts and develops the concept of SCBCP. Section 2 provides a brief review on supply chain simulation. In Section 3, the case study and the complexities in the "as is" state of the selected supply network are defined thoroughly while in Section 4, regarding the application of the Platform Strategy, some critical success factors (CSF) are extracted. Finally, Section 5 provides a simulation framework for modeling the defined system. In this section, the conceptual model described in Section 3 will be used as a basis for simulation modeling and a hierarchical model will be described. 


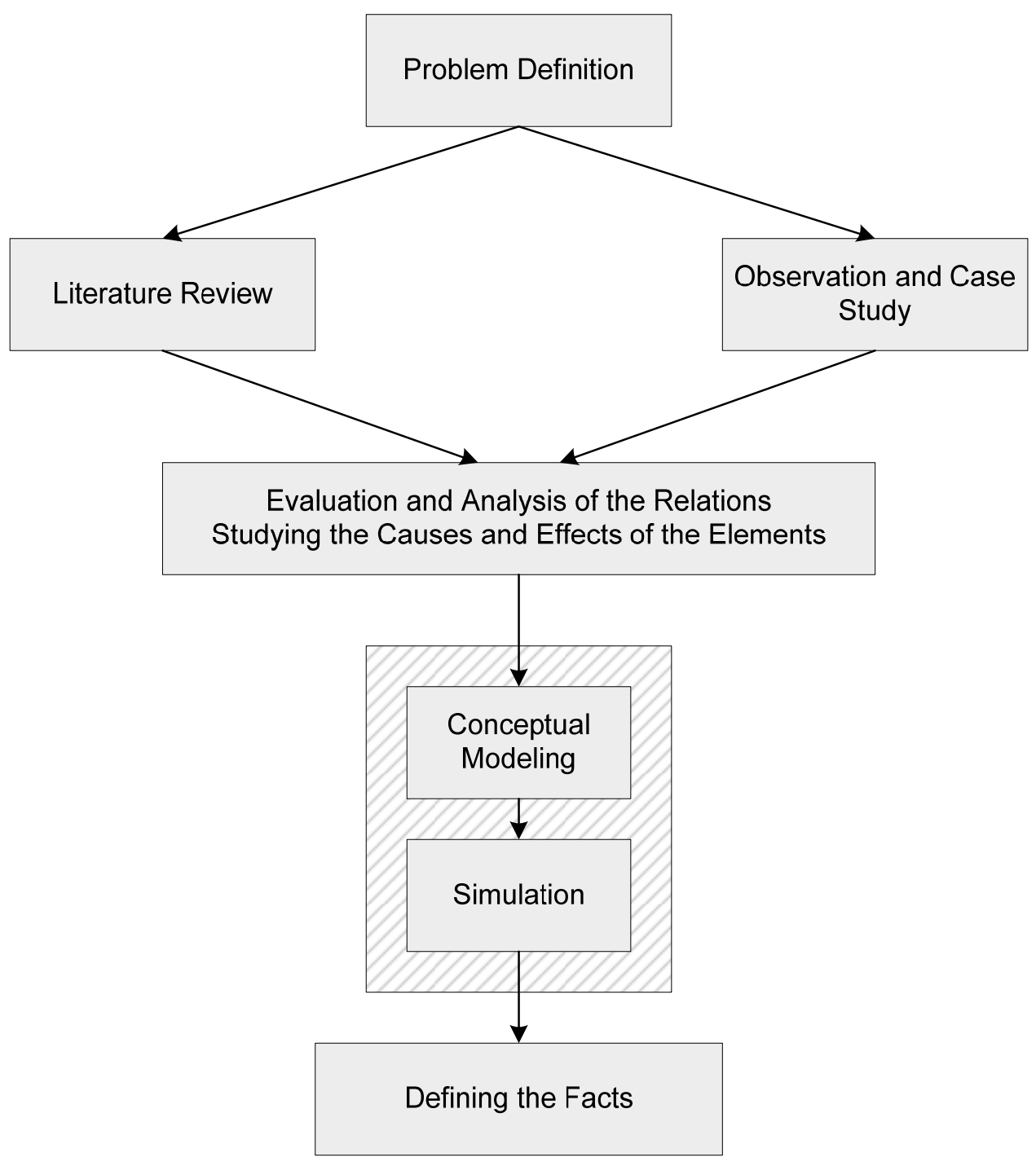

Figure 1. Research steps.

\section{Background: The Concept of Supply Chains based on Common Platforms (SCBCP)}

Supply chains are life cycle processes to support the physical, informational, financial, and knowledge aspects for moving products and services from suppliers to customers (Rabelo et al., 2007). Supply chain management is a process of integrating/utilizing suppliers, manufacturers, warehouses, and retailers, so that goods are produced and delivered at the right quantities, and at the right time, while minimizing costs as well as satisfying customer requirements (Chang and Makatsoris, 2006). In fact in today's market, there is no competition among companies but a competition among supply chains and it is the effective management of the supply chains that 
defines who will stay and who will leave the market (Vieira and Junior, 2005).

In this paper, we tend to emphasize the issue of producing variable products in a supply network. In fact, one of the most important key factors in today's tightening competition between companies is to increase the product variety and, at the same time, maintain the high quality and short delivery time. Considering the network nature of the supply chain system, providing variable products can cause a great complexity throughout the whole network. The end-result of this complexity is a proliferation of products, parts, suppliers, and a multiplicity of processes performed within a company (Dong, 2001). In order to reduce the level of complexity resulting from the increased product variety, concepts and strategies which are vital for the effective management of a supply chain system have been developed.

In recent decades, the Common Platform (CP) concept has been introduced as one of the important factors leading to valuable competitive advantages for industries. Meyer and Lehnard (1997) describe the platform as "a set of subsystems and interfaces that form a common structure from which a stream of derivative products can be efficiently developed and produced".

According to Robertson and Ullrich (1998), the platform can refer to a collection of assets, components, processes, knowledge, people and relationships. In the case of $\mathrm{CP}$ as the common components, other terms like "Component Commonality" or "Component Standardization" have been used in the literature. Hillier (2002) uses the term "commonality" to address the replacing of several parts by a single common part. It is important to note that common components can refer to shared parts in normal designed products or shared product "modules" in modular designed products $^{1}$. Figure 1, provides a better understanding of different levels of product development and the commonality of parts or modules in a product design based on the Common Platform.

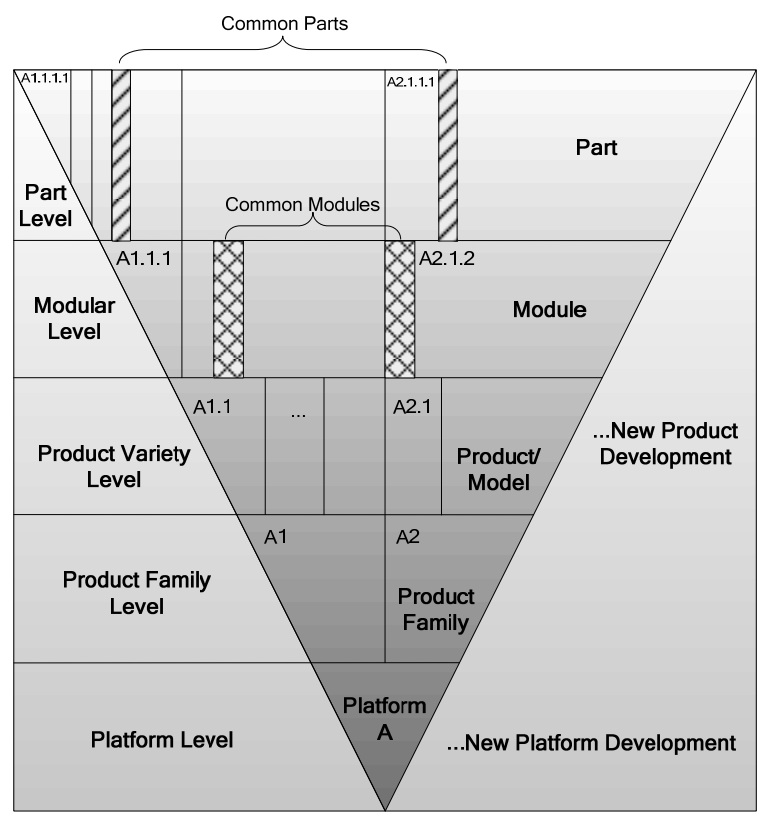

Figure 2. Product development levels.

According to this figure, the platform is the base of products or even product generations. Product families can be derived from a platform in a platform based design. Each product family is made of product models and each product model consists of several modules if the product is modular designed. In the highest level of Figure 1, modules are decomposed into parts. The product variety level includes the main output products and models to be manufactured. From a bottom up point of view, a single platform can be the basis

\footnotetext{
1 Modules are defined as physical structures that have a one-to-one correspondence with functional structures. They can be thought of quite simply as building blocks with defined interfaces. Modular products may be defined as machines, assemblies or components that accomplish an overall function through combination of distinct building blocks or modules (Eggen, 2003).
} 
of different product families and as a platform, common basis of technology, process or brand can be used in order to develop the product families and consequently manufacture variable products. From a top down point of view, the parts can be shared between different product modules and product modules can be shared between variable products in the case of modular product design. It is important to note that in this paper, the use of common parts in manufacturing a family of products (part commonality among products) is studied.

Based upon the Common Platform concept, great impacts have been impelled into the design and development of products and the relationships between different members of a supply chain (Heikkila \& Appelqvist, 2004). Some competitive advantages and benefits reported in CP area are as follows (Shafia and Fathollah, 2006; Brockelman et al., 2002; Huang, 2005):

- Reusable engineering and design

- Enable rapid development of derivative products

- Design and production based on modularity

- Reduced supplying of common components

- Faster innovation and new product development (NPD)

- Enable dramatic reductions in product time-tomarket

- Improvement of hardware maintainability and availability

- Increasing flexibility between and within plants

- Ability to move \& share resources between \& within plants

- Increasing variety of products

-Standardization of components \& parts commonality

- Improved planning and control in manufacturing

- Adjust for use and mass customization

- Shorter cycle times and reduced time to market

- Reduced number of components \& part variety
- Reduced complexity of production \& operation management

Taking a brief look to the benefits of CP strategy listed above, one can realize that most of these benefits are derived from or have an impact on the supply network of the product. In fact, one can say that the final goal of applying the Common Platform Strategy is to gain sustainable competitive advantages for the whole supply chain and quickly respond to the needs of the consuming market.

The Implementation of the Common Platform Strategy (or designing a common platform based supply chain) calls for special considerations and obligations in planning, management, control and synchronization in a supply chain management system. Thus, an integrated framework is considered for the supply chain management and the common platform which has lead to the introduction of Supply Chains Based on Common Platforms (SCBCP). SCBCP is introduced as an approach which encompasses the aforementioned vital considerations and obligations, including the utilization management of common resources along the chain, coordinating, enhancing and controlling supply and distribution networks under special circumstances of minimizing the production elements and maximizing the variety of products and services and changing management along the chain considering the variety of products.

Hence, we define SCBCP as

"A chain of related companies that work together as a network with the ability to share gains and risks and a resource sharing strategy that allows the chain members to develop derivative products for increasing value in an effective way."

According to Fathollah and Shafia (2006), there are three challenging issues encountered in the integration of SCM and CP:

(1) How to model and coordinate the supply chain business processes, specifically in the common platform area of supply chain workflows. 
(2) How to analyze the performance of an integrated supply chain network, and how a common platform can be employed to improve customer service and reduce inventory cost.

(3) How to evaluate dynamic supply chain networks and common platform to obtain a comprehensive understanding of decision-making issues related to supply network and CP configurations.

In order to decide about forming a platform based supply chain, organizations should consider the above issues and quantify the changes made in the form of possible advantages or disadvantages. This will call for a supply chain modeling approach wherein the designing issues and the impacts can be investigated and measured.

\section{Supply Chain Simulation}

According to Kim et al. (2004) four techniques are commonly used to model the supply chain for problem-solving: linear programming, integer/mixed-integer programming, network models and simulation modeling. Mathematical approaches often require too many simplifications to model realistic supply chain problems, although they may be valuable for gaining an understanding of general supply chain principles and effects. Hence, Simulation is considered as one of the most powerful techniques to apply within a supply chain environment (Terzi and Cavalieri, 2004).

The simulation approach offers several advantages. Simulation is recognized to allow more realistic observation of the supply chain behavior or of complex economic models in general. It allows an analysis of the supply chain dynamics and leads to an observation of the supply chain behavior along time. Moreover, it helps to analyze the organizational decision-making processes, the interdependencies between the actors of the supply chain, the consistency between the coordination modes and the decisional policies at the same time. According to Terzi and Cavalieri (2004), supply chain simulation has been investigated with continuous simulation and discrete event simulation (DES) and currently DES is the preferred mainstream method used for simulation of supply chains.

In order to analyze the impacts of integrating the Common Platform Strategy into the supply network of a company (forming the SCBCP), the simulation tool is used in this paper and a case study is used as the basis of the simulation framework development.

\section{Iran Khodro Automotive Company Case Study}

Iran khodro Company (IKCO) is a major car producer in the Islamic republic of Iran. Since its establishment in 1970, it has produced and assembled more than four million cars in about 50 different models. This company is in contract with some giant car producers in the world and implements the assembly line for the manufacturing of the automobiles designed and produced by these companies in the past. The goal is to localize the car manufacturing technology imported from the major car producers in the world. Besides, Iran khodro produces some car models designed by its own engineers (like Samand, the national Iranian car). Currently, the main car families produced and assembled by this company are Peugeot 405, Peugeot 206cc, Peugeot Pars, Samand, Logan and Roa.

Iran Khodro production system is based upon 4 main manufacturing technology platforms. Since there is a lot of variety in options and models of each car type and, at the same time, the majority of parts and processes in these models are similar and can be shared (between various models of one type and also between different types), this company is concerned with the utilization of the Common Platform Strategy. However, little has been done about it and the often occurring 
problems and issues make this company a good case for studying the impact and probable benefits of the Common Platform Strategy application.

By entering the international market and competition with global car producers, the essentiality of applying improvement strategies and manufacturing paradigms was much more sensed in IKCO. SCM and CP were two important factors that could perfectly speed up the improvement trend that IKCO was following. This company has done much more about organizing and managing its supply chain than the Platform Strategy. Since the last decade, the company has started an extensive study and research on its suppliers and tried to organize and manage its supply chain in order to reduce the chain costs, improve the quality and decrease the delivery time. One of the main results of this investigation was the creation of SAPCO2 ${ }^{2}$, which is the major first tier supplier of IKCO.

As mentioned, there are many issues concerning the CP strategy in Iran Khodro. In the following sections, we will study and model the supply chain system of this company and try to address one of the most important issues concerning the CP strategy in the supply chain of the company.

\subsection{Conceptual Modeling of the Case Study}

Figure 2 shows the conceptual model of the Iran Khodro supply chain. This is a high level model and includes the information and part flow for the majority of the company's products. It is important to note that this model will serve as a guide for modeling the flow of the specific parts chosen to be investigated in this research at a lower level. Therefore, appropriate levels of abstraction are applied in this model and it is tried to consider the processes and part flows which are most related to the purpose of this research and, at the same time, not to corrupt the validity of the high level model. However, it is important to understand the physical flow of products and the decision making logic of the company in order to recognize and model the problems and issues related to the specified case. The following section will provide a brief description of the high level conceptual model and discuss the supply network of IKCO.

According to customer orders, company visions and master production policies, a master production schedule (MPS) is created on a yearly basis.

SAPCO is the main supplier of IKCO which was established by IKCO itself to serve as the exclusive first tier supplier of the company. Generally most of the supply tasks and schedules of IKCO are conducted by SAPCO. Of course the IKCO's Orders Department is responsible for the supply of some specific parts. Hence, the MPS is presented to SAPCO and IKCO orders for the planning of the supply strategies and approaches. There are approximately 32 first tier suppliers, more than hundreds of second tier suppliers and an unknown number of third or superior tier suppliers which form the complex supply network of IKCO and have the responsibility for raw material supply, part production, and sub-assembly.

From the suppliers, the physical flow of the parts begins in the system. Produced parts are delivered to the Logistic Area (Part Receiving) where the initial inspections and quality control issues will be taken care of. Confirmed parts are then taken to the IKCO's warehouse.

\footnotetext{
${ }^{2}$ Supplier of Automotive Parts CO.
} 


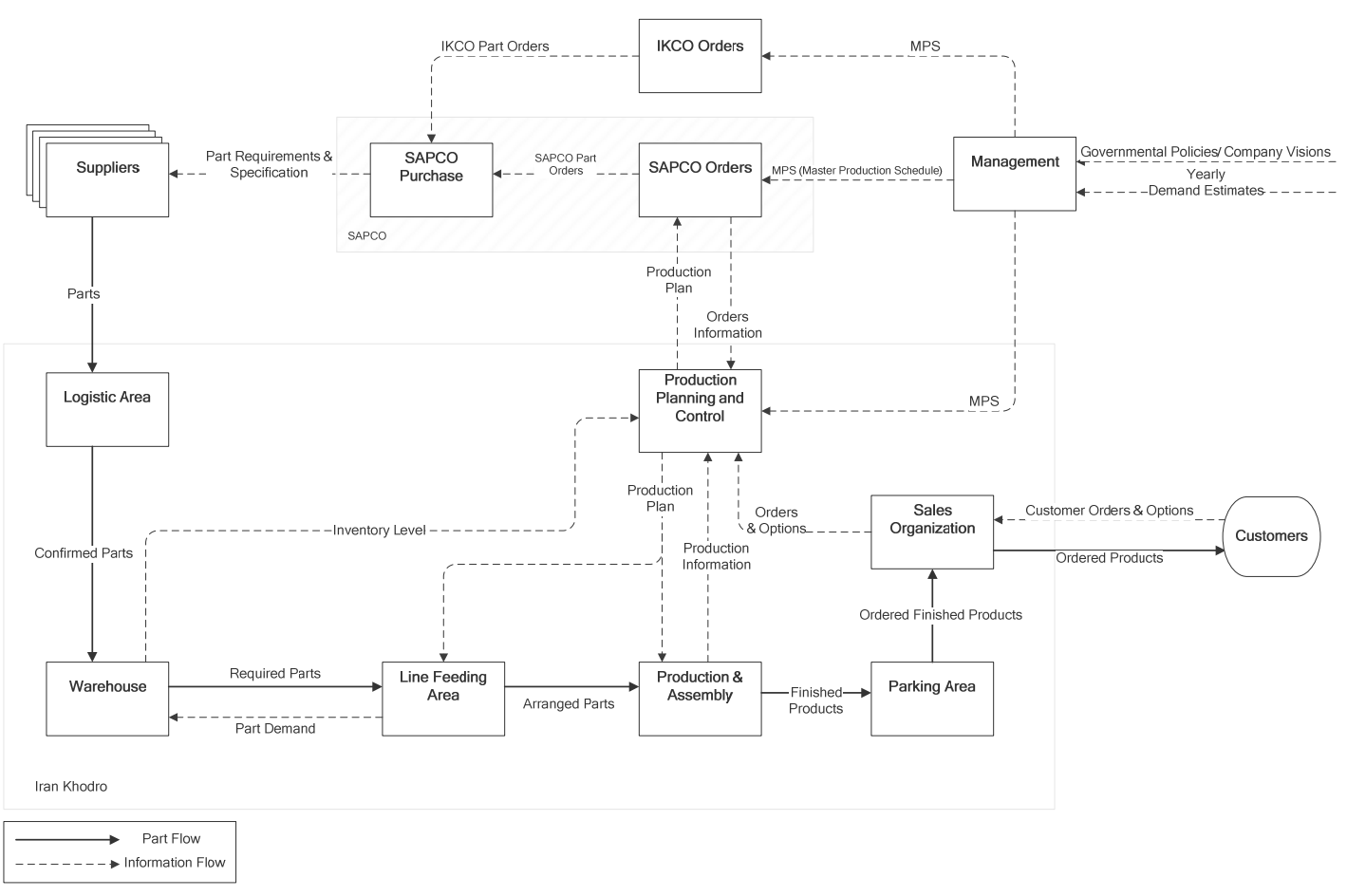

Figure 3. High level conceptual model of IKCO's order and delivery flow.

The Production planning and control division works as a brain for controlling and planning the system. Taking inputs like MPS, customer order options, inventory levels and orders information, this division generates the production plans on a monthly basis. The Line Feeding Department works as a facilitator and buffer for feeding parts to the production and assembly line. According to the weekly production plan (and informed revisions in the plan), the line feeding demands the needed parts from the warehouse and has to provide the right parts to the assembly line on time. In addition to the safety stocks held in the warehouse, the line feeding has its own safety stocks with much less amount and for a much shorter period of time.
Prepared parts are brought to the production and assembly line consisting of four production saloons. The finished products are taken to the parking area which serves as a large car warehouse. The sales organization then delivers the ordered products to end customers or sales representatives.

\subsection{Case Problem Statement}

The BOM of the company's products were studied and several company experts were interviewed trying to figure out the main problems and issues concerning IKCO supply chain which could possibly be solved by sharing parts or, in other words, by 
applying an appropriate Common Platform Strategy. The "Electrical Wire Harness" is one of the parts that were frequently mentioned in the interviews and concerning its variety, supplying of it it is one of the most important issues in IKCO. Reviewing the research on the wire harnesses in the automotive industry, it is revealed that variety of this part in different models of cars has long been quite a problem. Thus, in this paper, it is decided to study the supply chain of the electrical wiring harness $3^{3}$ in the Samand car family which is the main family of cars produced by IKCO.

The electrical wiring harnesses are defined as "a set of electric cables that are used to connect different elements in electromechanical or electronic systems" (Agard and Tollenaere, 2002). In the case of motor vehicles, a vehicle harness is an assembly of insulated wires or cables, bound together by plastic tape or textile braid and completed with terminals, plugs, bulb-holders and other fittings according to specification $4^{4}$. Such wiring provides the means through which power is supplied to the electrically operated components of a vehicle. Figure 3 shows an example of a wire harness of an automobile.

\footnotetext{
${ }^{3}$ It is important to note that the commonality and part sharing logic considered in this case can be extended to other parts and wire harness is just an instance of part commonality. In order to identify the potential parts to be shared, it is necessary to perform a feasibility test of functional, economical and technical properties of parts. Also, the productions process, supply chain characteristics and similarity of parts have to be considered and it is necessary to design a decision making model concerning the selection process, which is not the goal of this paper.

${ }^{4}$ There are different types of wire harnesses in a single vehicle. The main harness, the engine harness, and other subsidiary harnesses like the tail light harnesses, right or left front or back door harnesses and etc. The subsidiary harnesses are attached to the main harness and conduct the electrical power needed for specific parts of the vehicle. These subsidiary harnesses may be different according to different models of cars, for example the injectors wire harness which is used to provide the electrical power to the engine injectors in the cars with fuel injection engines.
}

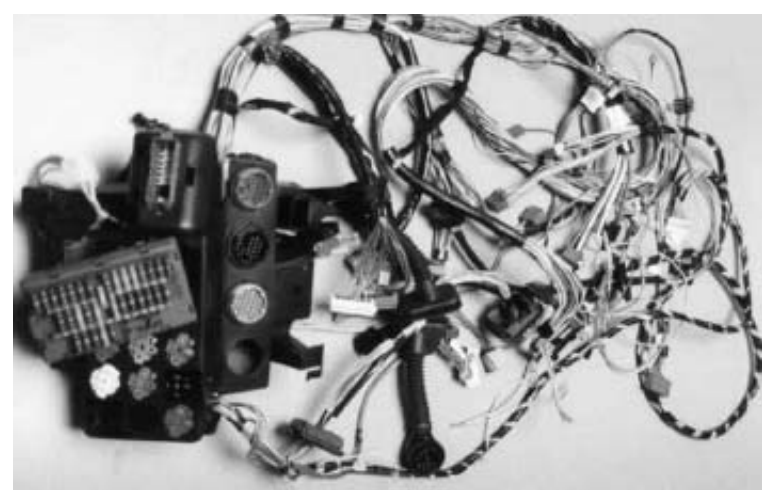

Figure 4. Electrical wire harness of an automobile (Agard \& Tollenaere, 2002).

Different types of subsidiary harnesses cause some variations in the main wiring harness because the main harness must have appropriate plugs and connectors for each subsidiary harness. Moreover, many options and specifications even in a single car family require specific harness elements (cables, plugs, shafts, connectors) in the main wiring harness. Therefore, diverse car models, requirements or options require diverse wiring harnesses, especially main wire harnesses. Thus, the main wire harness is chosen to be studied in this paper.

Considering the diversity of the wiring harnesses described above, and the fact that this part is one of the most expensive equipments in an automobile, some researches have been dedicated to studying and optimizing the design process of wire harnesses. $\mathrm{Ng}$ et al. (2000) provide a state of the art in the field of designing and planning the electrical wire harnesses. Agard and Tollenaere (2002) focus on the description of a product design problem for wide diversity with modular components and product-delayed differentiation for the realization of wire harnesses.

There are 12 models of Samand car produced by IKCO. These models are grouped into 4 main categories and their differences are in their engine 
type, body type or certain specifications. These models use different main wire harnesses (and a few of them share common ones). According to New Product Development experts of IKCO, applying part commonality is feasible concerning the few differences between the different types of MWHs for different Samand models. Of course the common part may have a higher price or longer production time ${ }^{5}$.

IKCO and SAPCO as the supplier of main wire harnesses, identify each type of $\mathrm{MWH}$ by a technical number. In spite of great similarity between main wire harnesses for different Samand models, these harnesses are treated completely as different parts in the supplying processes of IKCO and SAPCO because they have different technical numbers. Table 1 shows different Samand Models and the allocation of the main wiring harnesses to them by their technical numbers.

By focusing on the IKCO case study, it is intended to evaluate the behavior of main wire harness supply chain, before and after applying the common platform strategy (in the form of part sharing/part commonality). It is tried to identify the barriers and problems regarding the variety of different types of Samand main wire harnesses and also the benefits and improvements caused by applying the part commonality. Furthermore, this paper will provide a framework for the simulation of the Samand main wire harness supply chain with the purpose of "what if" analyzing the usage of one common MWH for the variety of Samand types.

\begin{tabular}{|c|c|c|c|c|c|c|c|c|c|c|}
\hline Samand Mod & Technical Number of MWH & 1151 & 1465 & 1443 & 1277 & 1439 & 1471 & 1355 & 1375 & 1329 \\
\hline Regular & Regular Samand (L3, SKD, IP16) & 1 & & & & & & & & \\
\hline & Regular CNG Samand & & & 1 & & & & & & \\
\hline & Regular TU5 Samand & 1 & & & & & & & & \\
\hline EL (Standard) & EL Samand (EL L3, EL SKD, EL IP16) & & & & & & & & 1 & 1 \\
\hline & EL CNG Samand & & & & & & & 1 & & \\
\hline LX & LX Samand & & & & 1 & & & & & \\
\hline & LX 85 Samand & & & & 1 & & & & & \\
\hline & LX TU5 Samand & & 1 & & & & & & & \\
\hline & LX CNG Samand & & & & & 1 & & & & \\
\hline & LX SKD Samand & & & & 1 & & & & & \\
\hline Sarir & Sarir Samand & & & & 1 & & & & & \\
\hline Suren & Suren Samand (P2) & & & & & & & 1 & & \\
\hline
\end{tabular}

Table 1. Samand models and their main wire harnesses.

\footnotetext{
5 This paper is not intended to study the technical feasibility of designing the main wiring harness as a common component. It is assumed that designing a common wire harness or more than one common wire harness as a replacement for the variety of main wire harnesses for one car family with different specifications is technically possible.
} 


\subsection{Detailed Description of the MWH Flow ("As is" State) \& Identification of Existing Problems}

In Figure 2, the high level part and information flow model in IKCO was illustrated. This model is almost common between the majority of parts procured and assembled by IKCO including the main wire harness. Of course its generality prevents the identification of specific attributes and functions which may be affected by the diversity of parts. Therefore, entering more details of the processes and functions is required. The detailed level will be identified according to the flow of MWH for the Samand family. It is important to note that the form and the level of details are related to the level of influence the CP strategy may have on each function.

Table 2 provides a detailed level of the wire harness flow through the system. This table is categorized according to the functional areas derived from the high level model. After describing the "as is" state of each functional area, Table 2 provides the barriers and problems caused by the variety of main wire harness for the Samand family. These barriers and problems are identified by the direct observation of the processes described in each functional area and interviewing the executive managers of related departments.

\section{Derivation and Analysis of Potential Benefits and Improvements Caused by Applying the CP Strategy (To be State)}

According to Table 1, currently 9 types of main wire harness are used in the production of 12 models of the Samand family. No part commonality approach is applied and the company does not consider the possibility of sharing some of these $9 \mathrm{MWH}$ types and decrease the multiplicity of parts, functions and processes engaged in the production, supply and assembly of them. By direct observation of the processes in IKCO and interviewing the managers in different departments of the company, the barriers and problems of supplying and assembling multiple wire harnesses were identified in Table 2. Solving any of these problems may lead to high levels of time and money savings for the company. As an example, it has happened that the lack of one special type of MWH has resulted in halt of the whole production line while other types of wire harnesses were available in the warehouse many times and there is a slight difference between these types of MWH. Technically, we assume that it is possible to design a kind of common wire harness between models of Samand.

Considering the replacement of 9 different types of $\mathrm{MWH}$ with a fewer number of common wire harness types, some benefits and improvements may occur in each functional area of the company. In fact, applying a common platform strategy in the form of part and process sharing may solve or mitigate the mentioned problems and barriers and lead to improvements and benefits for the company. In this section, we classify the perceived improvements and benefits as critical success factors (CSF) and identify the key performance indicators (KPI) for the CSFs in each functional area. In order to define a simulation framework for the existing system (in the next section), some data elements are gathered which can be useful for the development of the simulation model. Of course, the performance indicators can act as the variables that the simulation model measures and prove the identified CSFs. Note that these are some samples of KPIs and data elements and in order to develop a detailed simulation model, the exact and related data elements have to be extracted due to the problem situation.

In the literature, some researches have been dedicated to studying the supply chain critical success factors and also the critical success factors related to the supply chains based on common platform. Most of companies realize that in order to evolve an efficient and effective SCBCP, its 


\begin{tabular}{|c|c|c|}
\hline 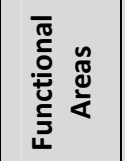 & Description of the "As Is" State & Barriers and Problems \\
\hline $\begin{array}{l}\frac{\lambda}{0} \\
\frac{2}{3} \\
\text { n }\end{array}$ & $\begin{array}{l}\text { According to long term and short term schedules provided by IKCO, SAPCO places } \\
\text { demands for different Samand MWHs from the two suppliers of wire harness. A } \\
\text { wide variety of harnesses are supplied according to the variety of Samand cars } \\
(12 \text { models) and the variety of wire harnesses for each car. In order to ensure the } \\
\text { order placement process, the suppliers maintain safety stocks for every type of } \\
\text { wire harness. The high variety of products and the use of exclusive wire } \\
\text { harnesses for each product will cause lots of operations regarding the order } \\
\text { placement process and, consequently, frequent changes in the production line. }\end{array}$ & $\begin{array}{l}\text { - Increasing the inventory level of wire harness } \\
\text { suppliers } \\
\text { - Frequent changes in the production plan and } \\
\text { setup time of wire harness suppliers } \\
\text { - Complexity in order placement and the sending } \\
\text { and receiving process } \\
\text { - Complexity in part transportation and logistics } \\
\text { - Improper use of production capacity by wire } \\
\text { harness suppliers }\end{array}$ \\
\hline 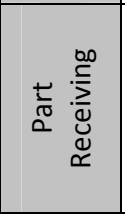 & $\begin{array}{l}\text { After sending the demanded wire harnesses by the suppliers, the parts are } \\
\text { entered to the part receiving area and the related information is registered, the } \\
\text { documents are controlled and the temporary and permanent acceptance of the } \\
\text { parts is confirmed. The information registering process, inspection and quality } \\
\text { control are performed for each type of wire harness (with different technical } \\
\text { numbers) separately. After checking technical and quality indicators, the received } \\
\text { parts are sent to warehouse for storage. }\end{array}$ & $\begin{array}{l}\text { - Complexity in the receiving process according } \\
\text { to high variety of parts } \\
\text { - Complexity in the inspection and quality control } \\
\text { process of the received parts } \\
\text { - Increasing the probability of mistakes and } \\
\text { functional errors }\end{array}$ \\
\hline 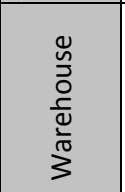 & $\begin{array}{l}\text { In the warehouse area, the wire harnesses are unloaded, categorized and stored } \\
\text { on different shelves. Two palettes of safety stock are considered for each type of } \\
\text { wire harness in order to prevent the lack of inventory when needed. The } \\
\text { permanent receipts are issued after the final transfer of parts to the warehouse. } \\
\text { Inventory control of the warehouse is performed by IKCO and the shortage lists } \\
\text { are announced to SAPCO. }\end{array}$ & $\begin{array}{l}\text { - Increase in the inventory level of wire harness } \\
\text { - Limitation of the warehouse space } \\
\text { - Difficulty in categorizing, coding and packaging } \\
\text { the diverse types of wire harnesses } \\
\text { - Increasing of the in-house transportation } \\
\text { because of the high variety of parts }\end{array}$ \\
\hline 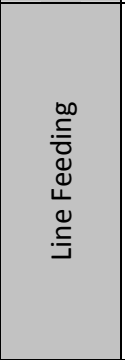 & $\begin{array}{l}\text { Based upon the generated schedules by production planning division, the line } \\
\text { feeding unit prepares and feeds the types of wire harnesses to the assembly } \\
\text { lines. All parts are classified into three types of A, B or C. Class A parts are massive } \\
\text { and have a high level of consumption in the production line. These parts are sent } \\
\text { to the production line without any changes in their containers. Class B parts } \\
\text { include parts with less volume which are sent to the line after changing their } \\
\text { containers (from palettes to boxes). Finally, class C parts are sent to the line } \\
\text { without any stop in the line feeding area. These parts have a low degree of } \\
\text { importance and frequency. Wire harnesses are mostly classified into A or B types. } \\
\text { After getting prepared in the line feeding area and keeping safety stocks (equal to } \\
\text { about two hours of consumption in the production line), these parts are sent to } \\
\text { the production and assembly lines. }\end{array}$ & $\begin{array}{l}\text { - High levels of inventory and safety stocks for } \\
\text { types of wire harnesses (MWH) } \\
\text { - Increasing the error coefficient due to high } \\
\text { variety of parts } \\
\text { - Increasing the frequency of transportation and } \\
\text { loading for different types of wire harnesses } \\
\text { - Space limitation }\end{array}$ \\
\hline 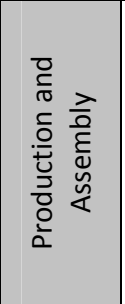 & $\begin{array}{l}\text { In saloon number } 2 \text { and saloon number } 4 \text { of the overall four production and } \\
\text { assembly saloons in IKCO, the wire harnesses are assembled on various models of } \\
\text { the Samand family. Safety work in progress (WIP) for different types of wire } \\
\text { harnesses are kept in the work stations. In accordance with the production plan, } \\
\text { the electrical wire harnesses are assembled in specific stations. }\end{array}$ & $\begin{array}{l}\text { - Increase in WIP for different types of wire } \\
\text { harnesses } \\
\text { - Occupying the space of production and } \\
\text { assembly stations } \\
\text { - Increasing the probability of errors and } \\
\text { mistakes in assembling the types of MWHs } \\
\text { - Increasing the probability of work station halts } \\
\text { due to the lack of a specific type of wire harness } \\
\text { - Decreasing the operational yield of work } \\
\text { stations }\end{array}$ \\
\hline 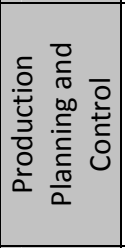 & $\begin{array}{l}\text { The planning division of the factory is responsible for transforming the } \\
\text { customers' needs to long term, short term or middle term production processes. } \\
\text { This section identifies that in accordance with the production policies and sales } \\
\text { schedules, how many products are to be produced in which period of time. On } \\
\text { the other hand, decisions about the time and quantity of supply and part } \\
\text { demands are made in this section. }\end{array}$ & $\begin{array}{l}\text { - Complexity in the Bill of Material (BOM) of the } \\
\text { Samand family due to the excessive variation in } \\
\text { the types of electrical wire harness } \\
\text { - Increasing the possibility of applying changes } \\
\text { and revisions to the production plan because of } \\
\text { lacking a special type of wire harness. } \\
\text { - Complexity in the demand placing process for } \\
\text { different types of wire harnesses. }\end{array}$ \\
\hline 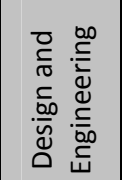 & $\begin{array}{l}\text { This area deals with designing or applying changes in the supply, production and } \\
\text { assembly processes both in supplier and main manufacturer level. }\end{array}$ & $\begin{array}{l}\text { - High levels of design and engineering costs } \\
\text { - Complexity in applying renovation. }\end{array}$ \\
\hline
\end{tabular}

Table 2. Detailed functions related to the "as is" flow of Samand MWH through the system. 
performance needs to be assessed. Based on researches developed in a supply chain environment, some critical success factors and performance metrics are presented. For example, Kleijnen and Smits (2003) have performed a survey on different performance metrics in supply chains and reviewed different supply chain simulation methods in order to study the impact of supply chain redesign on the value of the metrics. A. Gunasekaran et al. (2001) showed that performance can be considered within the strategic, tactical and operational level of management. As a same research, V.M.R.Tummala (2006) believed that we can evaluate SCM performance in terms of cost, time and flexibility. Also Gunasekaran et al. (2004) have proposed a framework for supply chain performance measurement and studied different performance measures. On the other hand, in the common platform environment, Luke A.Wissmann (2004) provided three performance factors for applying this strategy such as time, cost and ability of competitiveness, although Gonzalez et al. (2001) showed that one of the most important performance factors for evaluating the common platform strategy is flexibility.

After a brief review of this research, one can say that it is important to consider critical success factors for assessing SCBCP. Hence, in order to evaluate success of SCBCP, we consider three groups of critical success factors, as illustrated in Figure 4.

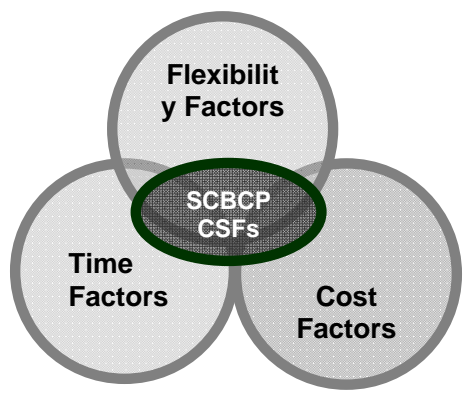

Figure 5. Critical Success Factors of a SCBCP.
The CSFs identified in each functional area of the case study are grouped into these three groups. Table 3 shows the classified CSFs, the key performance indicators and the gathered data elements for the evaluation of each functional area. It is important to note that many of the identified CSFs could be classified into more than one group. In the table, the most relevant classification for each CSF is considered.

\section{Defining a Simulation Framework}

In the previous sections of this paper, after conceptualizing the common platform strategy and its use in the supply network, we studied the impacts of a new concept called "Supply Chain" based on the common platform in an automotive company. In fact, we extracted the barriers and problems caused by the complexity of part and process multiplicity in the selected supply chain and identified the critical success factors and performance indicators according to the possible solution of these problems by the CP strategy.

It is important to validate the identified success factors by an analytical model and measure the impact of part commonality on each of the identified factors. Considering the complexity of the supply networks, discrete event simulation (DES) is chosen and in, this section of the paper, we will develop a simulation framework for the modeling of the defined system. It is tried to stick to a high level view and avoid the details. The goal of this section is to provide a conceptual framework for the simulation of the case study as a guide to simulation of other related systems and processes. The detailed simulation model can be studied as future research and variables to be measured can be chosen from the list of CSFs presented in Table 3 according to the objectives of the simulation modeling.

A Conceptual Framework (CF) is an underlying structure and organization of ideas which constitute the outline and basic frame that guides 
a modeler in representing a system in the form of a model (Derrick et al. 1989). There is some research dedicated to developing and comparing CFs for simulation. Derrick et al. (1989) introduced and compared about ten different frameworks for discrete event simulation. Rossetti and Chan (2003) have presented a simulation framework for a prototype object oriented supply chain. Vieira and Junior (2005) have developed a comprehensive conceptual model for the creation of supply chain simulation models. In their conceptual framework, they have considered the four elements of suppliers, manufacturer, retailers and the consumer market and used the ARENA software as the simulation programming platform.

In order to define the simulation framework for the supply chain model presented in this paper, we require making some specifications to the overall simulation framework models. It is important to note that the goal of developing a simulation framework in this paper is to measure the impact of the common platform strategy on a supply network, therefore, it is necessary to emphasize the supply chain stages which are most affected by the CP strategy. Hence, the framework presented in this paper consists of the functional decomposition of the defined supply network and developing a hierarchical modeling approach. Moreover, in order to execute the simulation process, one can follow the 9 operational stages stated below:

1- Scope Definition

2- Conceptual Model Development

3- Specific Model Development

4- Input Data Gathering

5- Data Input Analysis

6- Computer Model Development

7- Computer Model Validation and Verification

8- Applying the 'to be' state changes

9- Data Output Analysis and comparing the Results
In the case of developing a simulation model for the case study presented in this paper, stages 1 to 3 have already been described in the previous sections of the paper and a framework for stage 6 will be defined in the following sections.

\subsection{Defining a Hierarchical Simulation Model}

The hierarchical model to be presented in this part of the paper is developed to match the 'what if' analysis factors. It is tried to develop a more specific simulation framework than the existing supply chain simulation frameworks in accordance with the specifications of the problem stated in this paper and, at the same time, more general than the details of the case study presented in this paper to make it usable for other similar systems. A specific simulation model for this paper's case study is currently being developed using the Arena Simulation Software.

We have considered two hierarchical levels (level 0 and level 1) in order to define the simulation model in our framework for analyzing the goals of this paper. More detailed levels can be developed according to the specifications of the conceptual model while building the detailed simulation model matching the real world's circumstances. Level 0 is considered as the general level for building the sub models and, in level 1 , details of each sub model will be defined. It is also important to note that there are two types of flows in this simulation model. The physical flow includes parts in the chain and products in the assembly line (to which the specific parts will be assembled). It influences the inventory levels and assembly line functions and process times, transportation times and wait times are related to the physical flow of the model. The information flow consists of relationships between sub models and sub model entities. Production plans are one of the most important parts of the information flow. 


\begin{tabular}{|c|c|c|c|c|}
\hline 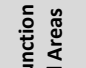 & \multicolumn{2}{|l|}{ Critical Success Factors } & Key Performance Indicators & Required Data Elements \\
\hline \multirow{3}{*}{$\frac{2}{\circ}$} & $\begin{array}{l}\text { - Improving the transportation and logistics system due to the } \\
\text { reduction of the variety in transportation facilities (loading and } \\
\text { unloading systems, palettes, packaging, vehicles, ...) } \\
\text { - Improving the logistics facilities (warehouses, docks, supply and } \\
\text { distribution channels, ...) }\end{array}$ & 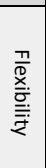 & \multirow{3}{*}{$\begin{array}{l}\text { - Supplier's setup times } \\
\text { - Variety of transportation facilities } \\
\text { - Supplier's lead times } \\
\text { - Number of order placements } \\
\text { - Production capacity of supplier } \\
\text { - Inventory and safety stock costs } \\
\text { - Costs of transportation and logistics } \\
\text { - Average time of part supply } \\
\text { - Variance of part supply times } \\
\text { - Delivery time } \\
\text { - External logistics times }\end{array}$} & \multirow{3}{*}{$\begin{array}{l}\text { - Information of production line } \\
\text { installation and setup times for } \\
\text { each product } \\
\text { - Number and types of products } \\
\text { to be shared } \\
\text { - Number of order placements in } \\
\text { a period of time }\end{array}$} \\
\hline & $\begin{array}{l}\text { - Decreasing the setup times due to the reduction of product diversity } \\
\text { and changes in the production plan in the supplier's production lines } \\
\text { - Improving the order placement and scheduling processes }\end{array}$ & 水 & & \\
\hline & $\begin{array}{l}\text { - Decreasing the common parts inventory level in the supplier's } \\
\text { warehouses } \\
\text { - Benefiting from the economics of scale by makers and suppliers } \\
\text { - Proper use of supplier's resources and capacities. }\end{array}$ & 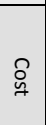 & & \\
\hline \multirow{3}{*}{ 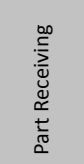 } & - Improving the orders registration process in receiving of parts & $\pi$ & \multirow[t]{3}{*}{$\begin{array}{l}\text { - Operations process times } \\
\text { - Process stages of operations }\end{array}$} & \multirow[t]{3}{*}{$\begin{array}{l}\text { - Time information of operations } \\
\text { processes }\end{array}$} \\
\hline & $\begin{array}{l}\text { - Facilitating the inspecting and quality control processes of the } \\
\text { received parts }\end{array}$ & -1 & & \\
\hline & - Decreasing the inventory levels of the common parts & $n$ & & \\
\hline \multirow{3}{*}{ 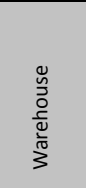 } & $\begin{array}{l}\text { - Standardizing the warehousing facilities } \\
\text { - Improving the in-house logistics }\end{array}$ & $\pi$ & \multirow{3}{*}{$\begin{array}{l}\text { - Maintenance and inventory control costs } \\
\text { - In house transportation and logistics costs } \\
\text { - Defect and inactivity costs } \\
\text { - In-house logistic times }\end{array}$} & \multirow{3}{*}{$\begin{array}{l}\text { - Maintenance and warehousing } \\
\text { costs } \\
\text { - Defects/ inactive inventory } \\
\text { rates } \\
\text { - Available warehouse space }\end{array}$} \\
\hline & $\begin{array}{l}\text { - Facilitating the process of classification, coding and arranging of parts } \\
\text { in the warehouse }\end{array}$ & $\dashv$ & & \\
\hline & $\begin{array}{l}\text { - Reducing the inventory levels of common parts } \\
\text { - Saving the warehouse area due to the reduction in variety of parts }\end{array}$ & $n$ & & \\
\hline \multirow{2}{*}{ 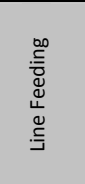 } & $\begin{array}{l}\text { - Facilitating the preparation and line feeding process } \\
\text { - Preventing and mitigating the errors in the preparation of various } \\
\text { parts } \\
\text { - Decreasing the loading and transportation repetition }\end{array}$ & $\dashv$ & \multirow[t]{2}{*}{$\begin{array}{l}\text { - Line feeding and part preparation times } \\
\text { - Number of loading and transportation } \\
\text { repetitions } \\
\text { - Inventory level average }\end{array}$} & \multirow[t]{2}{*}{$\begin{array}{l}\text { - Transportation time } \\
\text { - Transportation costs } \\
\text { - Process time } \\
\text { - Safety stock levels }\end{array}$} \\
\hline & $\begin{array}{l}\text { - Reducing the safety stock levels of common parts } \\
\text { - Saving the safety stock area }\end{array}$ & $n$ & & \\
\hline \multirow{3}{*}{ 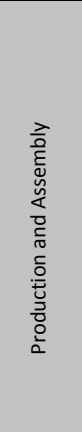 } & $\begin{array}{l}\text { - production line balance } \\
\text { - Standardizing the facilities of production and assembly stations } \\
\text { - Increasing the production flexibility } \\
\text { - Increasing the possibility of fast response to spontaneous and } \\
\text { changing demands } \\
\text { - Possibility of sharing or merging work stations } \\
\text { - Possibility of sharing or merging production factors (machines, tools, } \\
\text {...) }\end{array}$ & $\pi$ & \multirow{3}{*}{$\begin{array}{l}\text { - Line balance indicator } \\
\text { - Work station yields } \\
\text { - Average amount of work in progress (WIP) } \\
\text { - Average number of errors in time unit } \\
\text { the lack of parts } \\
\text { - Setup times } \\
\text { - Average time of line halt due to lack of } \\
\text { parts } \\
\text { - Cost of error exposure } \\
\text { - Time to adapt (needed response time to } \\
\text { demand changes) }\end{array}$} & \multirow[t]{3}{*}{$\begin{array}{l}\text { - Time information of work } \\
\text { stations } \\
\text { - Amount of work in progress } \\
\text { - Operational capacities } \\
\text { - Production area } \\
\text { - Line/ Production halt times }\end{array}$} \\
\hline & $\begin{array}{l}\text { - Decreasing the errors in production and assembly of parts } \\
\text { - Reduction of preparation and setup times } \\
\text { - Facilitating the solving of defects due to standardized elements }\end{array}$ & -1 & & \\
\hline & $\begin{array}{l}\text { - Reduction of the work in progress (WIP) } \\
\text { - Effective use of work stations' capacity and functional space } \\
\text { - Reduction of the production line halts due to lack of parts }\end{array}$ & $n$ & & \\
\hline 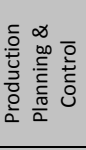 & $\begin{array}{l}\text { - Stability of planning (reducing the changes in plans) } \\
\text { - Comfortable management of BOM and MRP due to reduced variety } \\
\text { of elements } \\
\text { - Facilitating the planning, order placement and supplying process of } \\
\text { parts and materials }\end{array}$ & $\pi$ & $\begin{array}{l}\text { - Customer dissatisfaction amount } \\
\text { - Amount of scheduling and planning } \\
\text { stability } \\
\text { - Costs and numbers of each order } \\
\text { placement }\end{array}$ & $\begin{array}{l}\text { - The cost of frequent changes in } \\
\text { plan } \\
\text { - Information about the changes } \\
\text { made to production plan }\end{array}$ \\
\hline \multirow{2}{*}{ 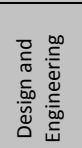 } & - Improving the management of changes in engineering & $\pi$ & \multirow{2}{*}{$\begin{array}{l}\text { - Initial investment costs } \\
\text { - Design and engineering costs } \\
\text { - Product design and engineering times } \\
\text { - New product development cycle times } \\
\text { - New product development rate }\end{array}$} & \multirow{2}{*}{$\begin{array}{l}\text { - Cost information of initial } \\
\text { investments } \\
\text { - Time and cost information of } \\
\text { prototype and product design }\end{array}$} \\
\hline & $\begin{array}{l}\text { - Facilitating the new product design and development } \\
\text { - Possibility of extending a basic design for other products }\end{array}$ & -1 & & \\
\hline
\end{tabular}

Table 3. CSFs, key performance indicators and required analytical data elements in a SCBCP. 
Level 0 is developed based on the conceptual model specified in Section 7 of this paper. Building a precise conceptual model of the system being studied is the most important step of simulation modeling in this level. The described functional areas of the system are considered as the main sub models of level 0 which are suppliers, warehouse, line feeding, production and assembly as well as the production planning and control. The common platform strategy has the most impact on these parts of the system as recognized in the previous sections. Figure 5 shows the sub models to be considered in level 0 of the simulation modeling.

It is important to note that the proposed level encompasses the supply chain to the point of distribution. The relationship with the distribution and consuming market is considered by the production planning sub model and the production plans this sub model generates according to the demands of the market. According to the case study presented in Section 7, at the beginning of each week the Production Planning and Control department generates the production plans for the 12 Samand models. According to Table 1, the required number of wire harnesses for each Samand model is calculated and the warehouse is filled at the beginning of the week. In the production and assembly line, the MWHs are assembled to the related Samand models and whenever the level of WIP falls down the limits, the Line Feeding Department sends the required number of MWHs to the production and assembly line. In the Line Feeding Department, there are safety stocks for each type of MWH and the shortage in the level of each safety stock leads to the demand of needed numbers from the Warehouse. Likely, the warehouse keeps safety stocks (with different amounts from the Line Feeding safety stocks) and places demands for the suppliers in the case of deficiency. Of course, there are some more complex relationships and control logic that keeps the inventory levels balanced throughout the chain.

In level 1, more detailed functions and elements of each sub model are defined. According to Table 2, it is apparent which functions the part multiplicity has the most impact on and, therefore, they have to be considered in level 1 . Table 4 illustrates a brief presentation of modeling in level 1 . In this table, the functions to be considered in each sub model are highlighted and the input and output data and elements for each sub model are defined. According to the importance of statistical distributions in the validity of a simulation model, the distributions to be defined in each sub model are also highlighted in Table 4. Moreover, the computer model developed in Arena 12 software based upon the presented framework is available on request.

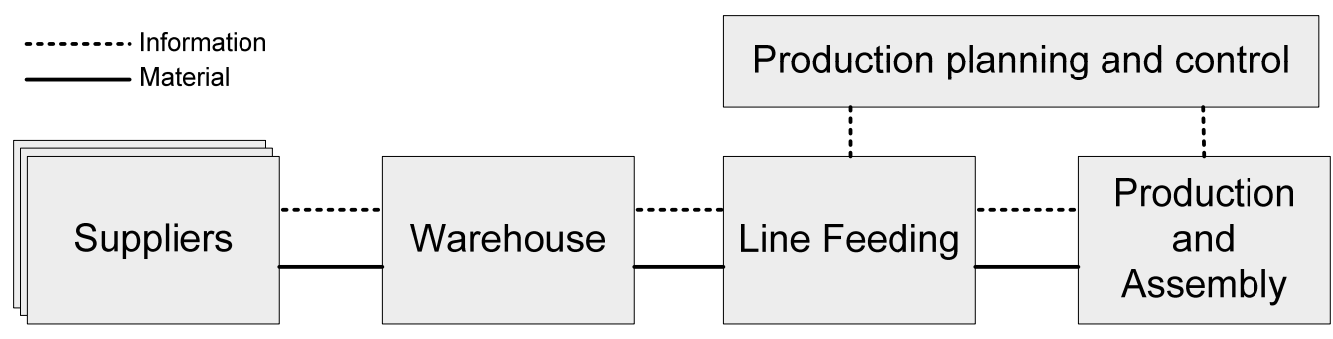

Figure 6. Sub models in level 0. 


\begin{tabular}{|c|c|c|c|c|}
\hline Sub Models & Main Functions & Inputs & Outputs & $\begin{array}{l}\text { Statistical } \\
\text { Distributions }\end{array}$ \\
\hline 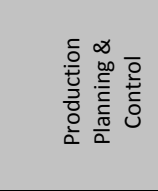 & $\begin{array}{l}\text { - Generating the production plans } \\
\text { - Calculating the required } \mathrm{MWHs}\end{array}$ & $\begin{array}{l}\text { - Production plans } \\
\text { - Bill of materials } \\
\text { - Schedules of working days and } \\
\text { hours }\end{array}$ & $\begin{array}{l}\text { - Updated variables of } \\
\text { Samand models to be } \\
\text { produced the following } \\
\text { week } \\
\text { - Updated variables of } \\
\text { needed MWH types }\end{array}$ & $\begin{array}{l}\text { Quantity of each } \\
\text { car model to be } \\
\text { produced each } \\
\text { week }\end{array}$ \\
\hline$\frac{\frac{n}{0}}{\frac{0}{0}}$ & $\begin{array}{l}\text { - Receiving and analyzing the MWH demands } \\
\text { - Manufacturing the needed MWH types } \\
\text { - Keeping safety stocks and inventories for } \\
\text { produced MWHs } \\
\text { - Generating the physical flow of MWH types }\end{array}$ & $\begin{array}{l}\text { - Form of supply network } \\
\text { - Demands for MWH types } \\
\text { - Manufacturing times } \\
\text { - Suppliers' inventory and safety } \\
\text { stock levels and calculation } \\
\text { formulas } \\
\text { - Transportation times }\end{array}$ & $\begin{array}{l}\text { - Updated variables of } \\
\text { suppliers inventory and } \\
\text { safety stock levels } \\
\text { - Physical flow of MWHs } \\
\text { - Average delivery times }\end{array}$ & $\begin{array}{l}\text { - Delivery times } \\
\text { - Transportation } \\
\text { times }\end{array}$ \\
\hline 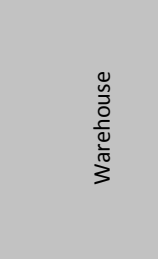 & $\begin{array}{l}\text { - Placing MWH demands to suppliers when } \\
\text { exceeding the safety stock levels } \\
\text { - Inspecting the received MWHs and } \\
\text { identifying the defective parts } \\
\text { - Keeping safety stocks for each type of } \\
\text { MWH } \\
\text { - Sending the required MWHs to Line } \\
\text { Feeding when needed }\end{array}$ & $\begin{array}{l}\text { - Safety stock levels calculation } \\
\text { - formulas } \\
\text { - Demands for MWH types } \\
\text { - Physical flow of MWHs } \\
\text { - Inspection process times } \\
\text { - Percentage of defective parts } \\
\text { - Transportation times }\end{array}$ & $\begin{array}{l}\text { - Updated variables of } \\
\text { Warehouse safety stock } \\
\text { levels } \\
\text { - Physical flow of MWHs } \\
\text { - MWH demand signals for } \\
\text { Suppliers } \\
\text { - Average warehouse safety } \\
\text { stock levels }\end{array}$ & $\begin{array}{l}\text { - Inspection times } \\
\text { - Response time to } \\
\text { the shortage of } \\
\text { MWH in Line } \\
\text { Feeding } \\
\text { - Transportation } \\
\text { times }\end{array}$ \\
\hline 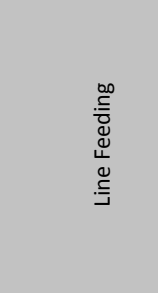 & $\begin{array}{l}\text { - Keeping safety stocks for each type of } \\
\text { MWH } \\
\text { - Placing MWH demands to Warehouse when } \\
\text { exceeding the safety stock levels } \\
\text { - Arranging the MWH types according to the } \\
\text { production sequence } \\
\text { - Checking the WIP levels on a timely manner } \\
\text { - Sending the required MWHs to Production } \\
\text { Line when needed }\end{array}$ & $\begin{array}{l}\text { - Safety stock levels calculation } \\
\text { formulas } \\
\text { - Updated variables of needed } \\
\text { MWH types } \\
\text { - Physical flow of MWHs } \\
\text { - Process times arrangement } \\
\text { - Transportation times }\end{array}$ & $\begin{array}{l}\text { - Updated variables of Line } \\
\text { Feeding safety stock levels } \\
\text { - Physical flow of MWHs } \\
\text { - MWH demand signals for } \\
\text { Warehouse } \\
\text { - Average line feeding } \\
\text { safety stock levels }\end{array}$ & $\begin{array}{l}\text { - Arrangement } \\
\text { times } \\
\text { - Response time to } \\
\text { the shortage of } \\
\text { MWH in } \\
\text { Production and } \\
\text { assembly Line } \\
\text { - Transportation } \\
\text { times }\end{array}$ \\
\hline 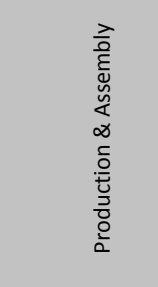 & $\begin{array}{l}\text { - Generating the required number of Samand } \\
\text { models to which the MWHs have to be } \\
\text { assembled } \\
\text { - Matching the relevant Samand models and } \\
\text { MWHs for each model } \\
\text { - Filling the WIP levels }\end{array}$ & $\begin{array}{l}\text { - Updated variables of Samand } \\
\text { models to be produced the } \\
\text { following week } \\
\text { - Physical flow of MWHs } \\
\text { - Samand models production } \\
\text { times } \\
\text { - MWH assembly process times } \\
\text { - Production lead time } \\
\text { - WIP calculation formulas }\end{array}$ & $\begin{array}{l}\text { - Updated variables of WIP } \\
\text { levels } \\
\text { - Assembled Samand } \\
\text { Models } \\
\text { - Assembly line down times } \\
\text { - Average WIP }\end{array}$ & $\begin{array}{l}\text { - Distribution of } \\
\text { Samand models } \\
\text { production times } \\
\text { - MWH assembly } \\
\text { process times }\end{array}$ \\
\hline
\end{tabular}

Table 4. Characteristics of sub models in level 1 of simulation modeling. 


\subsection{Performance Measures \& 'To Be' State Changes}

The inputs of the sub models in level 1 can be grouped into two categories: Input data or elements from other sub models, and input data from outside the model (data from real world). The outputs can also be grouped into two categories: Output data or elements to other sub models, and output performance measures.

Output performance measurement variables are one of the most important parts of simulation models because they specify the goals of the simulation and, in the case of decision making or improvement planning using simulation modeling, the output performance measurement variables are to be optimized. In Table 3 of this paper, key performance indicators have been identified for each functional area of the supply network presented here. Each of these performance indicators can be used as the output performance measure variables in simulation modeling and which to be used depends on the simulation goals. In this framework, we have considered five output performance measurement variables:

- Average supplier delivery times

- Average warehouse safety stock levels

- Average line feeding safety stock levels

- Average work In Process

- Assembly line down times (due to lack of MWHs)

Applying the Common Platform Strategy in the form of part commonality leads to a decrease in the number of MWH types for the same number of Samand models. According to Table 1, currently (the "as is" state), there are 9 types of MWHs for 12 types of Samand. The manufacturing and flow of these 9 types have been considered in the proposed simulation model. Technically, we are not sure how common these 9 types can become for the 12 car models. It has to be distinguished by a logic analysis or a mathematical model considering the technical and economical factors.
After finding the number of common parts, the rest of the work is obvious. Applying the changes in the simulation model which will affect the physical flow of MWHs in the model, delivery times and safety stock levels and comparing the simulation results in the 'As Is' state and 'To Be' state by statistical hypothesis tests.

By controlling the above performance measures along with all other identified performance indicators in a SCBCP and even optimizing the desirable indicators, it is quite easier to plan, coordinate and manage the effectiveness of a SCBCP.

\section{Conclusions and Future Research}

Variable products as a competitive advantage of today's companies cause complexity in the supply chain. Numerous different parts have to be supplied from different suppliers. This part multiplicity also has a negative impact on warehousing processes, for example, numerous safety stocks have to be kept for each type of parts. These difficulties in the supply network highlight the need for managing the part multiplicity in the chain. Designing the supply network based upon common platforms can possibly eliminate or mitigate many of the problems and barriers caused by chain complexity. Sharing parts can impact the flexibility, time and cost factors in the supply network.

In this paper, we investigated the impact of the Common Platform strategy in solving or mitigating the effects of complexity caused by product variety in supply networks. We studied the different aspects of the Common Platform (CP) Strategy and stated that applying the Common Platform calls for some considerations and obligations in planning, management, control and synchronization in a supply chain management system. Thus, we defined a new concept in designing supply chains called the supply chain based on Common 
Platform (SCBCP). From a product family perspective, we focused on part commonality as an aspect of Common Platform. Using the IKCO case study, we extracted the impacts of part proliferation on the supply network of this automotive company. Conceptually, we concluded that part commonality affects the functional areas of the selected automotive company including the supply, part receiving, warehouse, line feeding, production and assembly, production planning and control, and design and engineering. We also defined many aspects of these influences in each functional area. Samand car model was chosen as the car family and the main electrical wire harness as the part we investigated. By analyzing the main wire harness flow in the production of Samand car model, we extracted several flexibility, time and cost critical success factors for the application of a Common Platform Strategy. In order to control and optimize the CFS variables and ultimately contribute the planning, coordination and managing the effectiveness of a SCBCP it was important to use an analytical model. Therefore, we presented a simulation framework as a tool for studying the impact of part commonality on the supply network of the introduced case.

Future research on this topic can include the following:

1-Further definition and clarification of different issues and aspects of SCBCP

2-Investigating the relationships and effects of SC on $\mathrm{CP}$ and $\mathrm{CP}$ on $\mathrm{SC}$

3-Designing a decision support process for choosing parts to be standardized and shared between families of products.

4-Developing a logic analysis or mathematical model for defining the number of common part platforms concerning technical and economical specifications

5-Analyzing similar supply chains and investigating the CP strategy as case studies
6-Developing the detailed computer simulation model and analyzing the outputs for the defined and similar cases

7-Developing mathematical models for the analysis of SCBCP

8-Studying the characteristics of SCBCP in other industries and analyzing and comparing them with the automotive industry

9-Developing performance and effectiveness indicators in SCBCP

\section{References}

[1] Habchi, G., Berchet, C., 2003. A Model For Manufacturing Systems Simulation With a Control Dimension. Simulation Modeling Practice and Theory 11, 21-44.

[2] Heikkila, J., Appelqvist, P., 2004. Product Structures, Modularity and Platforms. Design of production system, Helsinki University of Technology.

[3] Guilherme, E., Vieira, Osmar, C. J., 2005. A Conceptual Model for the Creation of Supply Chain Simulation Models. Proceedings of the 2005 Winter Simulation Conference.

[4] Rabelo, L., Eskandaric H., Shaalan T., Helal M., 2007. Value chain analysis using hybrid simulation and AHP. International Journal of Production Economics 105, 536-547.

[5] Jain, S., Collins, L.M., Workman, R.W., Ervin, E.C., 2001. Development of a High-Level Supply Chain Simulation Model. Proceedings of the 2001 Winter Simulation Conference.

[6] Chang, Y., Makatsoris H., 2006. Supply Chain Modeling Using Simulation. International Journal of Simulation Vol. 2, No. 1.

[7] Ellram, L., Cooper, M., 1993. Characteristics of supply chain management and the implications for purchasing and logistics strategy. International Journal of Logistics Management, Vol. 4, No. 2, 1-10. 
[8] Dong, M., 2001. Process Modeling, Performance Analysis and Configuration Simulation in Integrated Supply Chain Network Design. Dissertation submitted to the Faculty of the Virginia Polytechnic Institute and State University.

[9] Meyer, Lehnard, 1997. The Power of Product Platforms: Building Value and Cost Leadership. New York: The Free Press.

[10] Fathollah, M., Shafia, M.A., 2006. A Survey of Common Platform Applications and Research Issues for Industries and Industrial Engineers. The International Journal of Applied Management and Technology, Vol. 4, Num 2, 18-46.

[11] Hillier, M.S, 2002. The costs and benefits of commonality in assemble-to-order systems with a $(Q, r)$ policy for component replenishment. European Journal of Operational Research 141, 570-586.

[12] Brockelman, S., Jones, D., Poe, K., 2002. Product and Technology Platforms. Research \& Technology Executive Council.

[13] Huang, G.Q, 2005. The power of product platforms in mass Customization. International Journal of Mass Customization, Vol. 1.

[14] Kim, C.S., Tannock, J., Byrne, M., 2004. State of the art review techniques to model the supply chain in an extended enterprise. Operations Management Division, University of Nottingham.

[15] Ulrich, K., Bradley, J.R., 2002. The effect of product variety on supply-chain performance. European Journal of Operational Research.

[16] Huang, G.Q., Zhang, X.Y., Liang, L., 2004. Towards Integrated Optimal Configuration of Platform Products, Manufacturing Processes, and Supply Chains. Journal of Operations Management.

[17] Lau, A.K.W., Yam, R.C.M., 2005. A case study of product modularization on supply chain design and coordination in Hong Kong and China. Journal of Manufacturing Technology Management.
[18] Er, M., MacCarthy, B., 2006. Managing product variety in multinational corporation supply chains: A simulation study. Journal of Manufacturing Technology Management.

[19] Walsh, K.D., Walsh, T.A, Hershauer J.C., Tommelein, I.D., Sawhney, A., 2002. Lead Time Reduction Via PrePositioning of Inventory In Industrial Construction Supply Chain. Proceedings of the 2002 Winter Simulation Conference.

[20] Terzi, S., Cavalieri, S., 2004. Simulation in the supply chain context: a survey. Computers in Industry 53 3-16.

[21] Agard, B., Tollenaere, M., 2002. Design of Wire Harnesses For Mass Customization, International Conference on Integrated Design and Manufacturing in Mechanical Engineering, May 14-16 2002.

[22] Ng, F.M., Ritchie, J.M., Simmons, J.E.L., 2000. The design and planning of cable harness assembly. Inst. Mechanical Engineers Proceedings, Vol 214 Part B.

[23] Gunasekaran, A., Patal, C., Tiritroglu, C., 2001. Performance Measures and Metrics in a Supply Chain Environment. International Journal of Operations and Production Management.

[24] Tummala, V.M.R., 2006. Assessing Supply Chain Management Success Factors: A Case Study. International Journal of Supply Chain Management.

[25] Gonzalez, J.P., Otto, K.N., Baker, J.D., 2001. Assessing Value In Platform Product Family Design. Res. Engineering Design.

[26] Derrick, E.J., Balci, O., Nance, R.E., 1989. A Comparison of Selected Conceptual Frameworks For Simulation Modeling. Proceedings of the 1989 Winter Simulation Conference.

[27] Rossetti, M.D., Chan, H.T., 2003. A Prototype Object-Oriented Supply Chain Simulation Framework. Proceedings of the 2003 Winter Simulation Conference.

[28] Kleijnen, J., Smits, M.T., 2003. Performance metrics in supply chain management. Journal of the Operational Research Society 0, 1-8. 
[29] Gunasekarana, A., Patel C., McGaughey, R.E., 2004. A framework for supply chain performance measurement. International Journal of Production Economics 87 333-347.

[30] Wacker, J. G., 1998. A definition of theory: research guidelines for different theory-building research methods in operations management. Journal of Operations Management 16, 361-385.

[31] Ellram, L. M., 1996. An Application of the Case Study Method in Logistics Research. The Journal of Business Logistics, Volume 17, No. 2, 93-138. 


\section{Authors Biography}

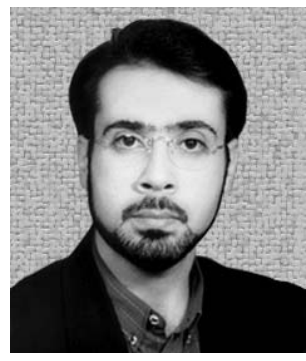

\section{Mehdi FATHOLLAH}

He holds a Ph.D. degree in industrial engineering from the Iran University of Science \& Technology. Dr. Fathollah teaches courses in production planning and supply chain management at Karaj branch of Azad University of Iran. His research activities focus on supply chain management, systems engineering, production and operations management and product architecture. He has completed his Ph.D. program in supply chain management and product architecture and has published two books and several academic papers in these fields. Currently, he collaborates with several industrial corporations and manufacturing organizations as a trainer, consultant and project manager.

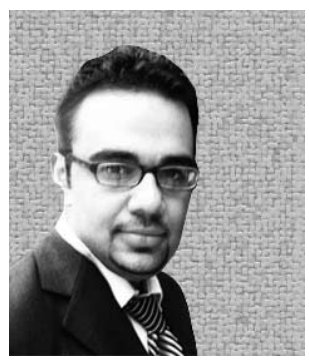

\section{Farzam TAHAM}

$\mathrm{He}$ is an industrial engineering student at the Iran University of Science \& Technology. His research interests include the modeling and analysis of supply chain systems, new product development and simulation modeling. He has several published conference and journal papers. His current research focuses on the effect of platform based product development on supply chain management. He has been involved in several industrial improvement projects as a senior member.

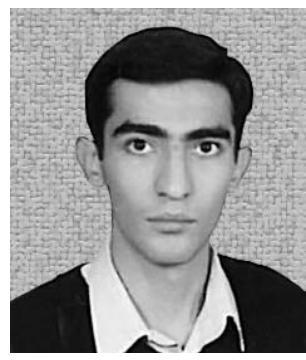

\section{Armin ASHOURI- RAD}

He is currently doing a master program in "Economical and Social System Engineering"at Sharif University of Technology and has a BS in industrial engineering from Iran University of Science and Technology. His research interests lie on simulation, system analysis design and development, scheduling, meta heuristics and optimization. 